\title{
Penggunaan Lumpur Sawit Fermentasi dengan Neurospora sp dan Suplementasi Ekstrak Daun Katuk (Sauropus androgynus) terhadap Performa Ayam Ras Petelur di Desa Srikaton
}

\author{
Utilization of Palm Oil Sludge Fermented with Neurospora sp and \\ Supplementation of Sauropus androgynus Leaf Extract on Performance \\ of Chicken Layer in Srikaton Village
}

Yosi Fenita, Irma Badarina, Basyarudin Zain, dan Teguh Rafian

Jurusan Peternakan, Fakultas Pertanian, Universitas Bengkulu

Jalan W.R. Supratman Kandang Limun Bengkulu 38371A

Email: yosifenita@yahoo.co.id

\begin{abstract}
This research was aimed to evaluate utilization of palm oil sludge fermented with Neurospora $s p$ and supplementation of Sauropus androgynus leaf extract on performance of layer chicken in Srikaton village. The research was conducted on June 3 through July 52014 in layer chicken in Srikaton village Kecamatan Pondok Kelapa, Kabupaten Bengkulu Tengah, Bengkulu Province. The experimental units were 60 layers aged 9 months, divided into 2 treatments with 30 layers placed in individual cage. Treatments were P1(Ration with $15 \% \mathrm{LSF}+0.6 \% \mathrm{EDK}$ ) and P2 (farmer ration). Results showed that supplementation of LSF and EDK reduced ration consumption, increased ration consumption, increased egg production percentage (\%), increased egg production, increased egg production/ mass production (gram), and increased ration convertion $(\mathrm{P}<0.05)$. Based on research result it is concluded that utilization of $15 \%$ palm oil sludge fermented with Neurospora sp and Supplementation of $0.6 \%$ Sauropus androgynus leaf extract in ration, did not increase ration consumption, however, it reduced egg production and improved ration convertion in layer chicken.
\end{abstract}

Key words : fermented palm oil sludge, katuk leaf extract, layer

\begin{abstract}
ABSTRAK
Penelitian ini bertujuan untuk mengevaluasi penggunaan lumpur sawit yang telah difermentasi dengan Neurospora sp dan ekstrak daun katuk (Sauropus androgynus) terhadap performa produksi ayam ras petelur. Penelitian ini dilaksanakan pada tanggal 3 Juni sampai dengan 5 Juli 2014 di peternakan ayam ras petelur, Desa Srikaton, Kecamatan Pondok Kelapa, Kabupaten Bengkulu Tengah, Provinsi Bengkulu, menggunakan 60 ekor ayam berumur 9 bulan yang terbagi dalam 2 perlakuan dengan 30 sampel yang ditempatkan pada kandang baterai individual (individual cage). Perlakuan terdiri dari P1 (ransum dengan 15\% LSF + 0,6\% EDK) dan P2 (ransum peternak). Hasil penelitian menunjukkan bahwa penggunaan LSF dan EDK menurunkan konsumsi ransum, meningkatkan persentase produksi telur (\%), meningkatkan produksi telur (butir), meningkatkan produksi telur/produksi massa (gram), dan meningkatkan nilai konversi ransum $(\mathrm{P}<0,05)$. Berdasarkan hasil penelitian dapat disimpulkan bahwa penggunaan lumpur sawit fermentasi pada taraf $15 \%$ dan ekstrak daun katuk (Sauropus androgynus) pada taraf 0,6\% dalam ransum tidak meningkatkan konsumsi ransum, tetapi dapat meningkatkan produksi telur dan memperbaiki konversi ransum ayam ras petelur.
\end{abstract}

Kata Kunci : Lumpur sawit fermentasi, ekstrak daun katuk, ayam ras petelur

\section{PENDAHULUAN}

Target konsumsi protein hewani di Indonesia masih belum tercapai. Peternakan ayam ras petelur merupakan salah satu alternatif penyedia sumber protein hewani yang relatif lebih cepat dan murah (Sari et al., 2012). Banyaknya pakan unggas yang masih impor seperti jagung, bungkil kedelai, dan tepung ikan (Sinurat, 2003) menyebabkan rendahnya 
ketersediaan dan mahalnya harga pakan (Sari et al., 2012).

Lumpur sawit fermentasi (LSF) merupakan salah satu pemecahan masalah bahan pakan alternatif yang memiliki ketersediaan yang cukup setiap tahunnya, harga beli murah, dan kandungan nutrisi tinggi. Fenita et al. $\left(2010^{\mathrm{b}}\right)$ menyatakan bahwa lumpur sawit setelah difermentasi oleh Neurospora sp meningkatkan kandungan protein kasar dari 13,57\% menjadi $23,45 \%$, dan menurunkan serat kasar dari $28,03 \%$ menjadi $17,34 \%$. Lumpur sawit yang sudah difermentasi memiliki kualitas nutrisi yang lebih baik dari pada lumpur sawit yang belum difermentasi.

Fenita et al. $\left(2013^{\mathrm{a}}\right)$ telah mencoba pemberian LSF sebanyak $15 \%$ pada ransum dapat meningkatkan kualitas telur, meningkatkan efisiensi pakan, dan menekan biaya produksi sebesar Rp. 650/kg pakan. Penggunaan LSF masih terbatas karena LSF defisiensi asam amino esensial yaitu metionin dan lisin, sehingga perlunya penambahan metionin dan lisin hingga kandungan metionin sebanyak $1,65 \%$ dan lisin $0,75 \%$ dalam ransum (Fenita et al., 2010 ${ }^{\mathrm{a}} ; 2010^{\mathrm{b}}$ ). Penggunaan LSF juga belum mengoptimalkan performa ayam ras petelur (Sari et al., 2012; Fenita et al., 2010 ${ }^{\mathrm{b}}$, sehingga perlunya suplementasi bahan tambahan yang dapat mengoptimalkan kualitas telur dan meningkatkan performa ayam ras petelur berupa ekstrak daun katuk (EDK)

Ekstrak daun katuk (Sauropus androgynus) kaya akan $\beta$-karoten dan vitamin $\mathrm{C}$, sehingga dapat meningkatkan warna kuning pada kuning telur (Santoso, 2007). Selain itu, penggunaan EDK pada ayam ras petelur dapat meningkatkan berat telur (Santoso, 2007). Hal ini didukung oleh Subekti (2007), penggunaan tepung daun katuk dan tepung ekstrak daun katuk dapat meningkatkan berat telur. Sari et al., (2012), pernah mencoba penggunaan LSF sebanyak $15 \%$ ditambah dengan EDK dapat meningkatkan berat telur, konsumsi ransum, produksi telur, dan memperbaiki konversi ransum dibandingkan penggunaan LSF tanpa EDK. Hal ini dikarenakan daun katuk memiliki kandungan asam benzoat. Putranto (2011) menyatakan bahwa asam benzoat pada daun katuk di dalam tubuh akan dikonversikan menjadi estradiol-17 $\beta$ benzoat yang dapat meningkatkan fungsi reproduksi dan merangsang pertumbuhan folikel sehingga ayam menghasilkan produksi telur yang lebih tinggi dan lebih efisien.

Diharapkan penggunaan lumpur sawit difermentasi Neurospora sp dan ekstrak daun katuk (Sauropus androgynus) pada ayam ras petelur dapat meningkatkan performa ayam dan memenuhi permintaan masyarakat akan telur yang murah dan bermutu tinggi.

\section{METODE PENELITIAN}

Penelitian ini menggunakan 60 ekor ayam berumur 9 bulan yang terbagi dalam 2 perlakuan dengan 30 sampel yang ditempatkan pada kandang baterai individual (individual cage). Perlakuan terdiri dari P1 (ransum dengan 15\% LSF + 0,6\% EDK) dan P2 (ransum peternak). 
Data konsumsi ransum, produksi telur, dan konversi pakan dianalisis dengan Uji-T menggunakan taraf kepercayaan $95 \%$.

Tabel 1. Komposisi dan kandungan nutrisi ransum Ayam Petelur selama penelitian

\begin{tabular}{lcc}
\hline \multirow{2}{*}{$\begin{array}{l}\text { Rahan Penyusun } \\
\text { Ransum (\%) }\end{array}$} & P1 & P2 \\
\cline { 2 - 3 } & ESF + & (Ransum \\
Jagung Giling & 53 & Peternak) \\
KLK & 25 & 30 \\
LSF & 15 & 0 \\
EDK & 0,6 & 0 \\
Dedak Halus & 4,02 & 30 \\
Lysin & 0,99 & 0 \\
Metionin & 0,39 & 0 \\
Mineral mix & 1 & 1 \\
\hline Total & 100 & 101 \\
\hline Kandungan Nutrisi $(\%)$ & \\
\hline Protein Kasar & 17,01 & 17,19 \\
SK & 6,08 & 4,83 \\
Kalsium & 3,56 & 3,94 \\
Phospor & 0,82 & 1,27 \\
Lemak & 5,14 & 5,96 \\
Lysin & 1,65 & 0,74 \\
Metionin & 0,75 & 0,38 \\
ME (kkal/kg) & 2702,17 & 2519,80 \\
\hline
\end{tabular}

\section{HASIL DAN PEMBAHASAN}

\section{Persentase Produksi Telur}

Dari hasil uji-T terlihat P1 memiliki rata-rata persentase produksi telur yang lebih tinggi secara nyata $(\mathrm{P}<0,05)$ dibandingkan dengan P2 (Tabel 1). Hal ini dikarenakan dalam EDK memiliki kandungan asam benzoat yang dapat memperbaiki persentase produksi telur. Sari et al. (2012) menyatakan suplementasi EDK memperbaiki persentase produksi telur ayam ras petelur yang diberikan pada pakan berbasis LSF.

\section{Produksi Telur (Butir/ekor)}

Perlakuan yang menggunakan ransum dengan LSF dan EDK memiliki produksi telur butir/ekor yang lebih baik dibandingkan dengan perlakuan menggunakan ransum peternak. Hal ini dapat ditunjukkan pada Tabel 1 bahwa produksi telur butir/ekor pada P1 lebih tinggi secara nyata $(\mathrm{P}<0,05)$ dibandingkan dengan P2. Lebih tingginya produksi telur butir/ekor dikarenakan EDK memiliki kandungan asam benzoat. Putranto (2011) menyatakan bahwa asam benzoat pada daun katuk di dalam tubuh akan dikonversikan menjadi estradiol-17 $\beta$ benzoat yang dapat meningkatkan fungsi reproduksi dan merangsang pertumbuhan folikel sehingga ayam menghasilkan produksi telur yang lebih tinggi dan lebih efisien. Terlebih lagi, kandungan energi pada P2 tidak memenuhi standar kebutuhan energi pada ayam ras petelur yaitu sekitar $2700 \mathrm{kkal} / \mathrm{kg}$, yang menyebabkan rendahnya produksi telur pada P2. Dimana kebutuhan energi yang dibutuhkan tidak terpenuhi dalam pakan sehingga ayam ras petelur tidak memiliki energi berlebih untuk betelur 
Tabel 2. Produksi telur ayam yang disuplementasi lumpur sawit fermentasi dan ekstrak daun katuk

\begin{tabular}{lrrc}
\hline \multicolumn{1}{c}{ Variabel yang diamati } & \multicolumn{1}{c}{ P1 } & \multicolumn{1}{c}{ P2 } & Ket. \\
\hline Persentase produksi telur $(\%)$ & $67,74^{\mathrm{a}}$ & $55,77^{\mathrm{b}}$ & $*$ \\
Produksi telur (butir/Ekor) & $37,93^{\mathrm{a}}$ & $31,23^{\mathrm{b}}$ & $*$ \\
Produksi massa (gram) & $2425,79^{\mathrm{a}}$ & $1981,32^{\mathrm{b}}$ & $*$ \\
\hline
\end{tabular}

Superscrip berbeda pada baris yang sama menunjukkan perlakuan berbeda nyata $(\mathrm{P}<0.05)$.

\section{Produksi Massa}

Penggunaan LSF dan EDK dalam ransum ayam ras petelur menunjukkan hasil lebih tinggi secara nyata $(\mathrm{P}<0,05)$ terhadap produksi telur/produksi massa dibandingkan dengan ransum peternak. Penelitian ini sesuai dengan hasil penelitian Santoso (2007), penggunaan EDK pada ayam ras petelur dapat meningkatkan berat telur. Penggunaan tepung daun katuk dan tepung ekstrak daun katuk dapat meningkatkan berat telur (Subekti, 2007).
Tingginya produksi massa sejalan dengan produksi telur, hal ini menunjukkan penggunaan LSF dan EDK memberikan nilai positif pada produksi telur. Sari et al. (2012) menyatakan bahwa suplementasi EDK dalam ransum berbasis LSF memberikan pengaruh positif terhadap produksi massa ayam ras petelur. Dari hal ini diduga adanya kandungan tertentu di dalam EDK yang dapat meningkatkan produksi massa.

Tabel 3. Konsumsi ransum harian dan konversi ransum selama penelitian

\begin{tabular}{lrrc}
\hline \multicolumn{1}{c}{ Variabel yang Diamati } & $\mathrm{P} 1$ & $\mathrm{P} 2$ & Ket. \\
\hline Konsumsi ransum (gram/ekor/hari) & $115,02^{\mathrm{b}}$ & $117,76^{\mathrm{a}}$ & $*$ \\
Konversi ransum & $2,78^{\mathrm{b}}$ & $3,81^{\mathrm{a}}$ & $*$ \\
\hline
\end{tabular}

Superscrip berbeda pada baris yang sama menunjukkan perlakuan berbeda nyata $(\mathrm{P}<0.05)$.

\section{Konsumsi Ransum}

Dari hasil uji-T, penggunaan LSF dan EDK memberikan nilai yang lebih rendah secara nyata $(\mathrm{P}<0,05)$ terhadap konsumsi ransum harian (Tabel 3). Hal ini terlihat konsumsi ransum pada P2 lebih tinggi dibandingkan dengan P1, ini dikarenakan adanya perbedaan energi dari kedua ransum tersebut, dimana pada P1 memiliki kandungan energi sebesar $2724,73 \mathrm{kkal} / \mathrm{kg}$ dan pada P2 memiliki kandungan energi sebesar 2519,80 kkal/kg.
Lebih rendahnya kandungan energi pada ransum $\mathrm{P} 2$ mengakibatkan meningkatnya konsumsi ransum pada ayam ras petelur. Menurut Amrullah (2003), ada dua faktor penting yang mempengaruhi konsumsi ransum yaitu kandungan energi dan suhu lingkungan. Susanto (2004) menyatakan konsumsi ransum pada ternak sangat 
dipengaruhi kandungan energinya. Konsumsi ransum akan meningkat apabila diberi ransum dengan kandungan energi yang rendah dan sebaliknya akan menurun apabila diberi ransum dengan kandungan energi yang tinggi (Amrullah, 2003; Susanto, 2004). Kandungan energi dalam ransum P2 tidak sesuai standar kebutuhan ayam ras petelur yang mengakibatkan konsumsi ransum menjadi diatas normal yaitu diatas 110 gram/ekor/hari. Rekomendasi Fenita et al. $\left(2013^{\mathrm{b}}\right)$, kandungan energi pada ransum adalah $2700 \mathrm{kkal} / \mathrm{kg}$ dan kandungan protein kasar pada ransum adalah 17\%. Amrullah (2003) menyatakan konsumsi ransum untuk ayam petelur fase layer adalah 110 gram/ekor/hari dengan berat badan ratarata ayam $1,8 \mathrm{~kg}$.

\section{Konversi Ransum}

Berdasarkan dari hasil uji-T, penggunaan LSF dan EDK menaikkan efisiensi produksi yang ditunjukkan oleh lebih rendahnya konversi ransum dengan penggunaan LSF dan EDK dibandingkan dengan ransum peternak (Tabel 3). Hal ini dikarenakan penggunaan LSF dan EDK tidak meningkatkan konsumsi ransum, tetapi dapat meningkatkan berat telur dan produksi telur, sehingga menurunkan konversi ransum dan meningkatkan efisiensi produksi. Sari et al. (2012) menyatakan bahwa penggunaan LSF sebanyak $15 \%$ ditambah dengan EDK dapat meningkatkan berat telur, produksi telur, dan memperbaiki konversi ransum. Nilai konversi ransum adalah jumlah konsumsi ransum dibagi dengan jumlah produksi massa. Fenita et al. $\left(2010^{\mathrm{b}}\right)$ mendefinisikan konversi ransum diukur dengan cara membandingkan jumlah ransum yang dikonsumsi dengan berat telur yang dihasilkan.

Pada P2 konversi ransum memiliki nilai yang tinggi, karena terlalu rendahnya kandungan energi dalam pakan. Semakin rendah kandungan energi dalam pakan akan membuat semakin tinggi nilai konversi ransum. Amrullah (2003) dan Susanto (2004) menyatakan bahwa ransum yang mengandung energi yang tinggi akan lebih rendah konversi ransumnya, dan sebaliknya.

\section{KESIMPULAN}

Berdasarkan hasil penelitian dapat disimpulkan bahwa penggunaan lumpur sawit fermentasi dengan Neurospora $s p$ pada taraf $15 \%$ dan ekstrak daun katuk (Sauropus androgynus) pada taraf 0,6\% dalam ransum tidak meningkatkan konsumsi ransum, tetapi meningkatkan produksi telur, dan memperbaiki konversi ransum ayam ras petelur.

\section{SARAN}

Perlunya penelitian lebih lanjut terhadap proses fermentasi lumpur sawit dengan menggunakan jenis kapang dan media fermentasi yang berbeda kepada jenis ternak petelur yang berbeda ditambah dengan mengkombinasikan suplementasi ekstrak daun katuk (Sauropus androgynus). 


\section{DAFTAR PUSTAKA}

Amrullah, I.K. 2003. Nutrisi Ayam Petelur. Lembaga Satu Gunungbudi. Bogor.

Fenita, Y., D. Kaharuddin, dan H. Bustaman. 2013 ${ }^{\mathrm{a}}$. Pemanfaatan Limbah Lumpur Sawit Fermentatif dan Ekstrak Daun Katuk dalam Pendampingan Usaha Budidaya Ayam Ras Petelur Menuju Kemandirian Usaha. Laporan Akhir Pelaksanaan Program Pengabdian kepada Masyarakat Berbasis Riset. Jurusan Peternakan Fakultas Pertanian Universitas Bengkulu.

Fenita, Y., U. Santoso, D. Kaharuddin, dan Nurmeiliasari. 2013 . Revitalisasi Lumpur Sawit Fermentasi dengan Suplemen Ekstrak Katuk dan Enkapsulasi Minyak Ikan Lemuru untuk Peningkatan Produksi Reproduksi dan Kualitas Telur. Laporan Tahunan Penelitian Strategis Nasional Tahun II. Fakultas Pertanian Universitas Bengkulu.

Fenita, Y., dan D. Kaharuddin. 2011. Pengaruh Lumpur Sawit Fermentasi dengan Suplemen Asam Amino Lisin, Metionin, Triptopan selama Produksi terhadap Performans dan Kualitas Internal serta Kadar Kolesterol Telur Ayam Ras. Jurnal Agroindustri Vol. 1 (2): 63-71.

Fenita, Y., U. Santoso, dan H. Prakoso. $2010^{a}$. Pengaruh Lumpur Sawit Fermentasi dengan Neurospora sp terhadap Perfomans Produksi dan Kualitas Telur. Jurnal Ilmiah Ternak dan Veteriner Vol. 15 (2): 88-96.

Fenita, Y., U. Santoso, dan H. Prakoso. 2010 ${ }^{\mathrm{b}}$. Pengaruh Suplementasi Asam Amino Lisin, Metionin, Tritopan dalam Ransum Berbasis Lumpur Sawit Fermentasi terhadap Perfomans Produksi dan Kualitas Telur Ayam Ras. Jurnal Sain Peternakan Indonesia Vol. 5 (2): 105-114.

Putranto, H. D. 2011. Pengaruh Suplementasi Daun Katuk terhadap Ukuran Ovarium dan Oviduk serta Tampilan Produksi Telur Ayam Burgo. Jurnal Sains Peternakan Indonesia Vol. 6 (2): 103-114.

Sari, R. P., D. Kaharuddin, U. Santoso, dan Y.Fenita. 2012. Pengaruh Suplementasi Ekstrak Daun Katuk (Sauropus androgynus) dalam Ransum Berbasis Lumpur Sawit Fermentasi Terhadap Performans Ayam Ras Petelur. Jurnal Sains Peternakan Indonesia Vol. 7 (2): 8192.

Santoso, U. 2007. Pengaruh Penambahan Ekstrak Daun Katuk terhadap Kualitas Telur dan Berat Organ Dalam. Jurnal Sain Peternakan Indonesia Vol 2 (1): 5-10.

Sinurat, Arnold P. 2003. Pemanfaatan Lumpur Sawit untuk Bahan Pakan Unggas. Wartazoa Vol. 13 (2): 39-47.

Subekti, S. 2007. Komponen Sterol dalam Ekstrak Daun Katuk (Sauropus androgynus L. Merr) dan Hubungannya dengan Sistem 
Reproduksi Puyuh. Disertasi. Departemen Ilmu Nutrisi dan Teknologi Pakan Institut Pertanian Bogor. Bogor.

Susanto, S. R. 2004. Pengaruh Perbedaan Tingkat Protein dalam Ransum dengan Penambahan Probiotik terhadap Produksi Itik Indian tunner.
Skripsi. Jurusan Produksi Ternak

Fakultas Pertanian Universitas Sebelas Maret. Surakarta. http://jurnal.unipa.ac.id/index.php/pe ternakan/article/download/381/pdf.

Diunggah pada tanggal 23 September 2014. 